\title{
Field study on the accumulation of trace elements by vegetables produced in the vicinity of abandoned pyrite mines
}

\author{
Paula Alvarenga a,b,*, Isabel Simões a, Patrícia Palma ${ }^{\mathrm{a}, \mathrm{c}}$, Olga Amaral ${ }^{\mathrm{a}}$, João Xavier Matos ${ }^{\mathrm{d}}$ \\ a Departamento de Tecnologias e Ciências Aplicadas, Escola Superior Agrária, Instituto Politécnico de Beja, Rua Pedro Soares S/N, Apartado 6155, 7800-295 Beja, Portugal \\ b UIQA - Unidade de Investigação Química Ambiental, Instituto Superior de Agronomia, Universidade Técnica de Lisboa, Tapada da Ajuda, $1349-017$ Lisboa, Portugal \\ c CIMA - Centro de Investigação Marinha e Ambiental, CIMA, FCT, Edifício 7, Piso 1, Universidade do Algarve, Campus Universitário de Gambelas, $8005-139$ Faro, Portugal \\ ${ }^{\mathrm{d}}$ Laboratório Nacional de Energia e Geologia, U. Recursos Minerais e Geofisica, Beja, Portugal
}

\section{H I G H L I G H T S}

- Soils in kitchen gardens near pyrite mines are heavily contaminated with $\mathrm{As}, \mathrm{Cu}, \mathrm{Pb}$, and $\mathrm{Zn}$.

- Soil is mainly neutral, due to soil amendment, which contributes to the low bioavailability of TE.

- Generally, vegetables contain levels of these elements characteristic of uncontaminated plants.

- Risk is considerable where the soil pH is acidic, triggering high $\mathrm{Zn}$ bioavailable concentrations.

- If the soil pH is not controlled, there is a risk of consuming metal contaminated vegetables.

\section{A R T I C L E I N F O}

\section{Article history:}

Received 27 August 2013

Received in revised form 18 October 2013

Accepted 25 October 2013

Available online xxxx

\section{Keywords:}

Soil contamination

Mining activities

Iberian Pyrite Belt

Trace elements

Bioavailability

Edible plants

\begin{abstract}
A B S T R A C T
To evaluate the accumulation of trace elements (TE) by vegetables produced in the vicinity of abandoned pyrite mines, eighteen different small farms were selected near three mines from the Portuguese sector of the Iberian Pyrite Belt (São Domingos, Aljustrel and Lousal). Total and bioavailable As, $\mathrm{Cu}, \mathrm{Pb}$, and Zn concentrations were analyzed in the soils, and the same TE were analyzed in three different vegetables, lettuce (Lactuca sativa), coriander (Coriandrum sativum), and cabbage (Brassica oleracea), collected at the same locations. The soils were contaminated with $\mathrm{As}, \mathrm{Cu}, \mathrm{Pb}$, and $\mathrm{Zn}$, since their total concentrations exceeded the considered soil quality guideline values for plant production in the majority of the sampling sites. The maximum total concentrations for those TE were extremely high in some of the sampling sites (e.g. $1851 \mathrm{mg} \mathrm{As} \mathrm{kg}^{-1}$ in São Domingos, $1126 \mathrm{mg} \mathrm{Cu} \mathrm{kg}^{-1}$ in Aljustrel, $4946 \mathrm{mg} \mathrm{Pb} \mathrm{kg}^{-1}$ in São Domingos, and $1224 \mathrm{mg} \mathrm{Zn} \mathrm{kg}^{-1}$ in Aljustrel). However, the soils were mainly circumneutral, a factor that contributes to their low bioavailable fractions. As a result, generally, the plants contained levels of these elements characteristic of uncontaminated plants, and accumulation factors for all elements $<1$, typical of excluder plants. Furthermore, the estimated daily intake (EDI) for $\mathrm{Cu}$ and $\mathrm{Zn}$, through the consumption of these vegetables, falls below the recommended upper limit for daily intake of these elements. The sampling site that stood out from the others was located at São João de Negrilhos (Aljustrel), where bioavailable Zn levels were higher, a consequence of the slight acidity of the soil. Therefore, the $\mathrm{Zn}$ content in vegetables was also higher, characteristic of contaminated plants, emphasizing the risk of $\mathrm{Zn}$ entering the human food chain via the consumption of crops produced on those soils.
\end{abstract}

(C) 2013 Elsevier B.V. All rights reserved.

\section{Introduction}

The Iberian Pyrite Belt (IPB) is one of the largest metallogenetic provinces of massive sulphide deposits in the world (Pérez-López et al., 2008). The IPB exploitation dates back to the time of the Roman

\footnotetext{
* Corresponding author at: Department of Applied Sciences and Technologies, Escola Superior Agrária - Instituto Politécnico de Beja, Rua Pedro Soares S/N, Apartado 6155, 7800-295 Beja, Portugal. Tel.: +351 284314 300; fax: + 351284388207.

E-mail address: paula.alvarenga@ipbeja.pt (P. Alvarenga).
}

Empire, and was very active during part of the nineteenth and the twentieth centuries (Matos and Martins, 2006). Populations have developed around these mining sites and tended to explore small farms in the vicinity of the mining areas (e.g. mine tailings, locally with ore waste). The incomplete closure process and abandonment of some of these mines did not reverse this situation and they still live there and farm soils that are potentially affected by mining activities. Several studies, aiming the assessment of the potential risk of accumulation of trace elements in food crops grown in soils potentially affected by mining activities, have been developed around the world (e.g. Boularbah 